\title{
Periodicity and environmental drivers of apical and lateral growth in a Cerrado woody species
}

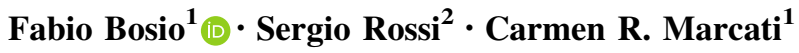

Received: 3 August 2015/ Accepted: 4 March 2016/Published online: 23 March 2016

(C) Springer-Verlag Berlin Heidelberg 2016

\begin{abstract}
Key message Apical and lateral growth are seasonal in a Cerrado species, and these events are related to each other and linked with climatic and environmental features.

Abstract In the Cerrado, a tropical ecosystem with seasonal rainfall, we investigated the timing of leaf production and cambial activity, and checked whether these features are related to each other and with climatic and environmental factors. Between September 2011 and December 2012, sampling of main stem and vegetative phenological observations of Kielmeyera grandiflora (Wawra) Saddi (Calophyllaceae) were done monthly to assess seasonality in leaf production and cambial activity, and to compare these features with each other. To check the relationship of bud opening and the onset of cambial activity with climatic and environmental features, the average temperature and day length, and the precipitation sum in a time window ranging from 1 to 30 days before the occurrence of these events were recorded, and the coefficient of variation was calculated. Leaf production and cambial activity were seasonal. Bud opening occurred in September 2011 and August 2012,
\end{abstract}

Communicated by M. Shane.

Electronic supplementary material The online version of this article (doi:10.1007/s00468-016-1383-8) contains supplementary material, which is available to authorized users.

Fabio Bosio

fabiobotanico@yahoo.com.br

1 Departamento de Ciência Florestal, Faculdade de Ciências Agronômicas, UNESP-Univ Estadual Paulista, Rua José Barbosa de Barros, 1780, Botucatu, SP 18610-307, Brazil

2 Département des Sciences Fondamentales, Université du Québec à Chicoutimi, Chicoutimi, QC G7H 2B1, Canada during the dry season. The onset of cambial activity occurred in October both in 2011 and 2012, 1-2 months after bud opening, at the beginning of the rainy season. The cambium was dormant in May, during the rainy season. Photoperiod and temperature showed low coefficients of variation in the time window before bud opening and onset of cambial activity, while rainfall presented a high coefficient of variation. Thus, both apical and lateral growth are seasonal events in Cerrado species, and are related to each other. A set of climatic and environmental features is related with seasonal growth, among which photoperiod and temperature may be important in the regulation of these events.

Keywords Budding - Cambium - Kielmeyera grandiflora $\cdot$ Leaf production $\cdot$ Phloem $\cdot$ Xylem

\section{Introduction}

Tropical ecosystems show great diversity in plant species and functional types (Borchert 1999; Clarke and Gaston 2006). Due to this diversity, different patterns of activity in apical (buds) and lateral (vascular cambium) meristems are expected. Among growth patterns, seasonal growth is a common feature in tropical species (see Venugopal and Krishnamurthy 1987; Rivera et al. 2002). Considering the relationships between apical and lateral seasonal growth, bud opening and activation of the vascular cambium may be related in some species, but no definitive rule could be drawn (see Rajput and Rao 2001b; Morel et al. 2015). These observations give origin to the following question: do apical and lateral growth in tropical trees consist of phenologically related events?

Concerning the relationship between bud opening and environmental features, the increase in photoperiod is the 
major signal involved in bud opening in a representative number of tropical species (Rivera et al. 2002; YáñezEspinosa et al. 2006). However, a positive relationship between maximum temperature and bud opening was observed in three tropical species from Mexico (YáñezEspinosa et al. 2006), suggesting the importance of this feature in bud reactivation. Although temperature appears to be an important feature related to bud opening, information on this relationship is still scarce for tropical species.

Regarding the relationships between seasonal lateral growth and climatic factors, the rainy period has been linked with the seasonality in cambium activity (Rao and Rajput 1999; Marcati et al. 2006a, 2008; Costa et al. 2013). In some species, the onset of cambial activity is synchronous with the onset of the rainy season (Krepkowski et al. 2011; Wang et al. 2013), and in many species the period of cambial activity and radial increment overlaps the rainy season (see Aljaro et al. 1972; Rao and Rajput 1999; Dié et al. 2012). Worbes (1995) states that a period of 2-3 months with less than $60 \mathrm{~mm}$ of monthly rainfall generates water stress and induces dormancy of the vascular cambium. In many species, the vascular cambium remains dormant during the dry season (Rao and Rajput 2001; Marcati et al. 2006a, 2008). However, some histological studies show that in areas with seasonal rainfall the onset of cambial activity can occur just before the start of the rainy season in some species (Dave and Rao 1982; Rao and Rajput 2001), which raises the question whether factors other than precipitation may be related to reactivation of the cambium.

The Cerrado is a Brazilian phytogeographic domain in the tropical zone (see Coutinho 2006). The Cerrado has various kinds of vegetation, including a savannah vegetation, known as cerrado sensu stricto (Oliveira-Filho and Ratter 2002). Rainfall in the Cerrado is seasonal: there is a rainy season in October-April, and a dry season in MaySeptember (Coutinho 2002). There is also a seasonal variation in temperature between summer and winter: the summers are hot and winters are cold (Coutinho 2002). As the Cerrado has many species with signs of seasonal apical and lateral growth (see Coradin 2000; Rivera et al. 2002; Marcati et al. 2006b), it is an ideal environment to study the relationships between seasonal weather and periodic growth.

In this study we assessed the periodicity and environmental drivers of apical and lateral growth in Kielmeyera grandiflora (Wawra) Saddi (Calophyllaceae), a Cerrado woody species. $K$. grandiflora is a typical species from the Cerrado areas (Durigan et al. 2004; Santos et al. 2011; Caddah et al. 2012), and is found in all states of Brazil where this phytogeographic domain occurs. As some species of the same genus have signs of seasonal apical and lateral growth (see Coradin 2000; Marcati et al. 2006b), this raises the possibility that $K$. grandiflora may have meristems showing periodic activity.

\section{Materials and methods}

\section{Study site}

The study was conducted in a "cerrado sensu stricto" area in Rubião Junior district $\left(22^{\circ} 53^{\prime} 11^{\prime \prime} \mathrm{S}, 48^{\circ} 29^{\prime} 17^{\prime \prime} \mathrm{W}\right)$, Botucatu, São Paulo, Brazil. The vegetation in the area is composed of a herbaceous-shrub layer in association with sparse trees. The climate is warm temperate, with annual mean temperature of $20.3{ }^{\circ} \mathrm{C}$; the minimum temperature in the coldest month can reach $0{ }^{\circ} \mathrm{C}$, and the maximum in the warmest month $40{ }^{\circ} \mathrm{C}$ (see Coutinho 2002; Cunha and Martins 2009). The annual rainfall of $1400-1500 \mathrm{~mm}$ is distributed throughout the year, although a dry period occurs between May and September (see Coutinho 2002; Cunha and Martins 2009). The soil is classified as oxisol, a deep and low nutrient availability soil with high concentrations of aluminium and iron (Motta et al. 2002).

\section{Bud and leaf phenology}

Bud and leaf phenology in $K$. grandiflora were monitored monthly from September 2011 to December 2012. In each field visit the phenology was recorded on a number of sample trees varying between 22 and 45 . The low height of trees facilitated the observations of phenological phases (see Table 1 Supplementary data). The phenological phases were identified according to the Morellato et al. (1989) procedure, modified by the addition of subdivisions in some categories. The phenological phases observed were: (a) leaf primordium emergence, the appearance of the red or light-green coloured leaf primordia; (b) young leaves, characterized by expanding, red coloured leaf blades; (c) expanded leaves, fully expanded, bluish-green leaves; (d) senescent leaves with colour changing to yellow or with brown spots on their surface; (e) leaf fall, when at least one of the following characteristics were observed, the leaf drops easily from the branch, presence of leaf scars at the apex of the branch, presence of voids in the canopy or leafless branches.

A semi-quantitative value was attributed to each phenological phase according to the Fournier (1974) procedure, modified by a reduction in the number of phenological classes, and redistribution of percentages in the remaining values. The assigned values ranged from 0 to 3 , whether a phenological phase was lacking (0), present on between 1 and $50 \%$ (1), between 50 and $70 \%$ (2), or more than $70 \%$ (3) of the crown. 


\section{Cambial activity and differentiation of vascular tissues}

Activity of the vascular cambium in $K$. grandiflora was monitored monthly from September 2011 to December 2012. Three to five different trees were checked on each date. A sample of approximately $2 \mathrm{~cm}^{3}$, containing bark, cambial zone and the recently formed secondary xylem was taken from each tree at breast height. They were removed from the main stem with a saw, hammer and chisel. In periods when the bark separated easily from the trunk (bark slippage), sampling was performed with a saw and stylus.

Samples were stored for about 1 month in CRAF III fixative (chromic acid, glacial acetic acid and formaldehyde, Berlyn and Miksche 1976). After fixation, cubes of $3 \mathrm{~mm}^{3}$ were cut from the samples, dehydrated in ascending alcohol series, and passed through a process of pre-infiltration with a solution of methacrylate resin and ethanol $99.9 \%$ (1:1) for 7 days. Samples were infiltrated with pure methacrylate resin for 25-30 days, and embedded in methacrylate resin (Bennett et al. 1976). They were then sectioned at 4-5 $\mu \mathrm{m}$ along the transverse, tangential and radial planes using a rotary microtome. The sections obtained were stained for $5 \mathrm{~min}$ with toluidine blue in phosphate buffer $\mathrm{pH} 4.7$ that produced a metachromatic staining (O'Brien et al. 1964; O'Brien and McCully 1981), and observed under a light microscope at magnifications of $400-1000 \times$.

The vascular cambium was considered active when signs of cell division in the cambial zone were observed in terms of mitosis phases, phragmoplast and newly formed anticlinal or periclinal cell walls in the initial and mother cells (Evert 1963; Farrar and Evert 1997; Frankenstein et al. 2005). The dormant period occurred when there was no evidence of cell divisions in the cambial zone, and, in tangential sections, the radial walls of fusiform initial and mother cells were thick, and with prominent primary pitfields, giving the radial cell wall a "beaded aspect". Secondary xylem was considered in differentiation when at least one of the following characteristics was observed: enlargement of xylem derivatives, deposition of secondary wall and lignification (see Evert 2006). Secondary phloem was considered to be differentiating when the enlargement of phloem derivatives and/or dispersion of P-protein and presence of nuclei in the developing sieve-tubes was observed (see Evert 2006).

\section{Climatic data and data analysis}

Temperature and rainfall data were obtained from the weather station belonging to the Faculdade de Ciências Agronômicas, Universidade Estadual Paulista, installed in an open field located $9 \mathrm{~km}$ from the study site. Photoperiod data were obtained from Time and Date website (Time and Date 2014).

Weather data were averaged (temperature and photoperiod) or cumulated (rainfall) at time windows varying between 1 and 30 days preceding the events of leaf primordia emergence and cambium activity. As variability depends on the sample mean, the coefficients of variation were calculated to evaluate the variability between years, which allowed the measure of dispersion (standard deviation) to be standardized to the mean.

\section{Vouchers}

Vouchers were deposited at the Herbarium "Irina Delanova De Gemtchujnicov" (BOTU) and stem samples were deposited in the Wood Collection "Profa. Dra. Maria Aparecida Mourão Brasil” (BOTUw).

\section{Results}

\section{Bud and leaf phenology}

All phenological phases showed a clear seasonal pattern (Fig. 1). Leaf primordium emergence occurred with high intensity once per year, in September 2011 (52.17\% of trees) and August 2012 (86.67\% of trees). The peak was followed by a drastic reduction in leaf primordium emergence, occurring only on a few branches of the crown. Young leaves peaked in the same months as leaf primordium emergence, but decreased gradually in the successive months (between 7 and $86 \%$ of trees still showed young leaves in October-May).

Expanded leaves were sporadic in September 2011 and August 2012, being leaves remaining from the previous growth period. In October 2011 and September 2012, 1 month after the peaks in leaf primordium emergence and young leaves, an abrupt increase in mature leaves was observed (from 13 to $100 \%$ in 2011 and from 13 to $86 \%$ in 2012), indicating that leaf expansion was nearly complete. The trees were fully foliated until April 2012, when the percentage of trees with mature leaves began to decrease. This reduction occurred until August 2012.

Leaf senescence and leaf fall spread over several months. The first senescent leaves were observed in November of both years, but on a small number of trees and with low intensity (between 4 and $5 \%$ of trees). From February 2012, $70 \%$ of trees had senescent leaves, but with low intensity, and in August trees were almost without senescent leaves. Leaf fall began in February, and increased during the following months, culminating in July, when more than $90 \%$ of the trees lost their leaves, 

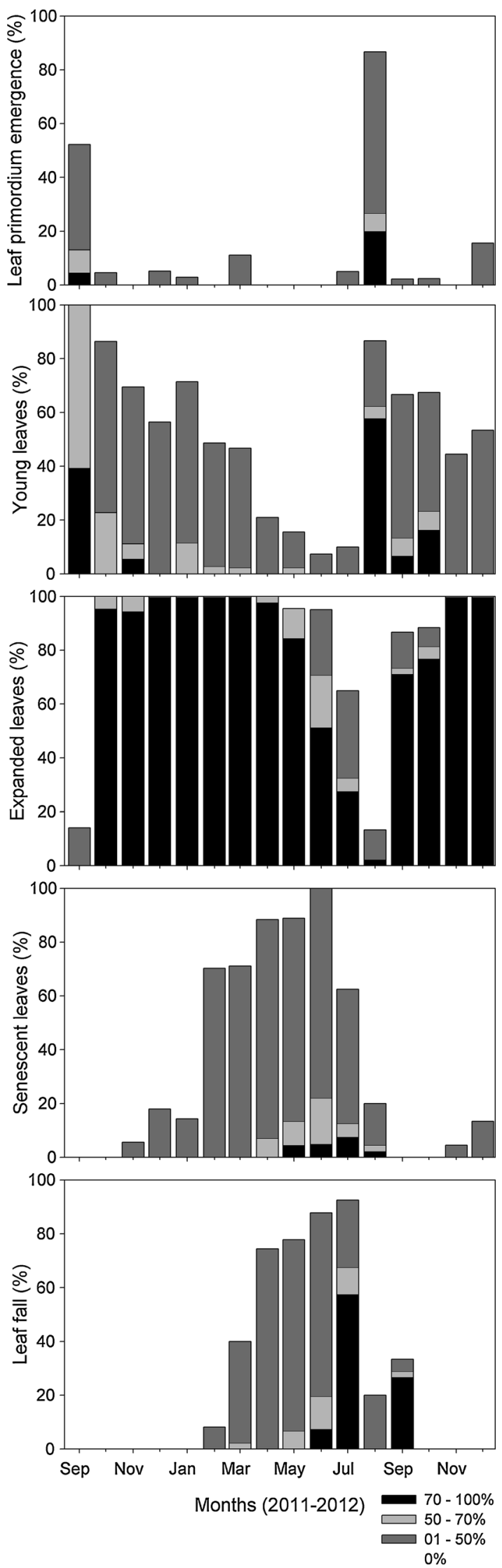

४Fig. 1 Percentage of trees expressing phenological phase and percentage of trees in each phenogical degree category

and $57 \%$ were classified at the degree 3 in phenological scale. In August, the last leaves fell. In September 2012, a fire occurred in the study area that led to the fall of the young leaves. Regarding the leafless period, in general trees remained without leaves for 20 days; some were leafless for 30 days $(n=4)$, and others for 45 days $(n=3)$. Thus, this species was considered to be deciduous.

\section{Cambial activity and differentiation of vascular tissues}

The vascular cambium showed seasonal activity (Figs. 2, 3). In September 2011 and between May-September 2012 the vascular cambium was dormant, without evidence of cell division (Fig. 3a). In this period, the radial walls of fusiform initial cells in tangential sections were thick with numerous pit fields, giving the wall a "beaded" aspect (Fig. 3b). The onset of cambium activity occurred in October in both years (Fig. 2a), when signs of cell division in the cambial zone were observed in terms of mitosis, phragmoplast (Fig. 3d, f) and newly formed anticlinal or periclinal cell walls (Fig. 3e). In this period, the radial walls of fusiform initials in tangential sections were thin and smooth, and primary pit fields were not prominent (Fig. 3f). The differentiation of xylem and phloem was also seasonal (Fig. 2b, c), and these processes were simultaneous with the beginning of cambium activity. Phloem and xylem differentiation extended until May and June, respectively, about 1 and 2 months after the end of cambial activity. The vascular cambium remained active for seven months and differentiation of secondary xylem and phloem occurred for about 8-9 months.

\section{Relationship between bud opening and vascular cambium}

In both years, the onset of vascular cambium activity and the beginning of xylem and phloem differentiation occurred in October, 1-2 months after leaf primordium emergence. In this period, more than $60 \%$ of trees showed the leaves fully developed. Dormancy of vascular cambium and ending of xylem and phloem differentiation corresponded with the increasing of senescent leaves and leaf shedding.

\section{Climatic and environmental features during the monitoring}

Between August 2011 and December 2012, the mean temperature was $22.1^{\circ} \mathrm{C}$, with an absolute minimum of $2.4{ }^{\circ} \mathrm{C}$ recorded in August 2011, and an absolute maximum 

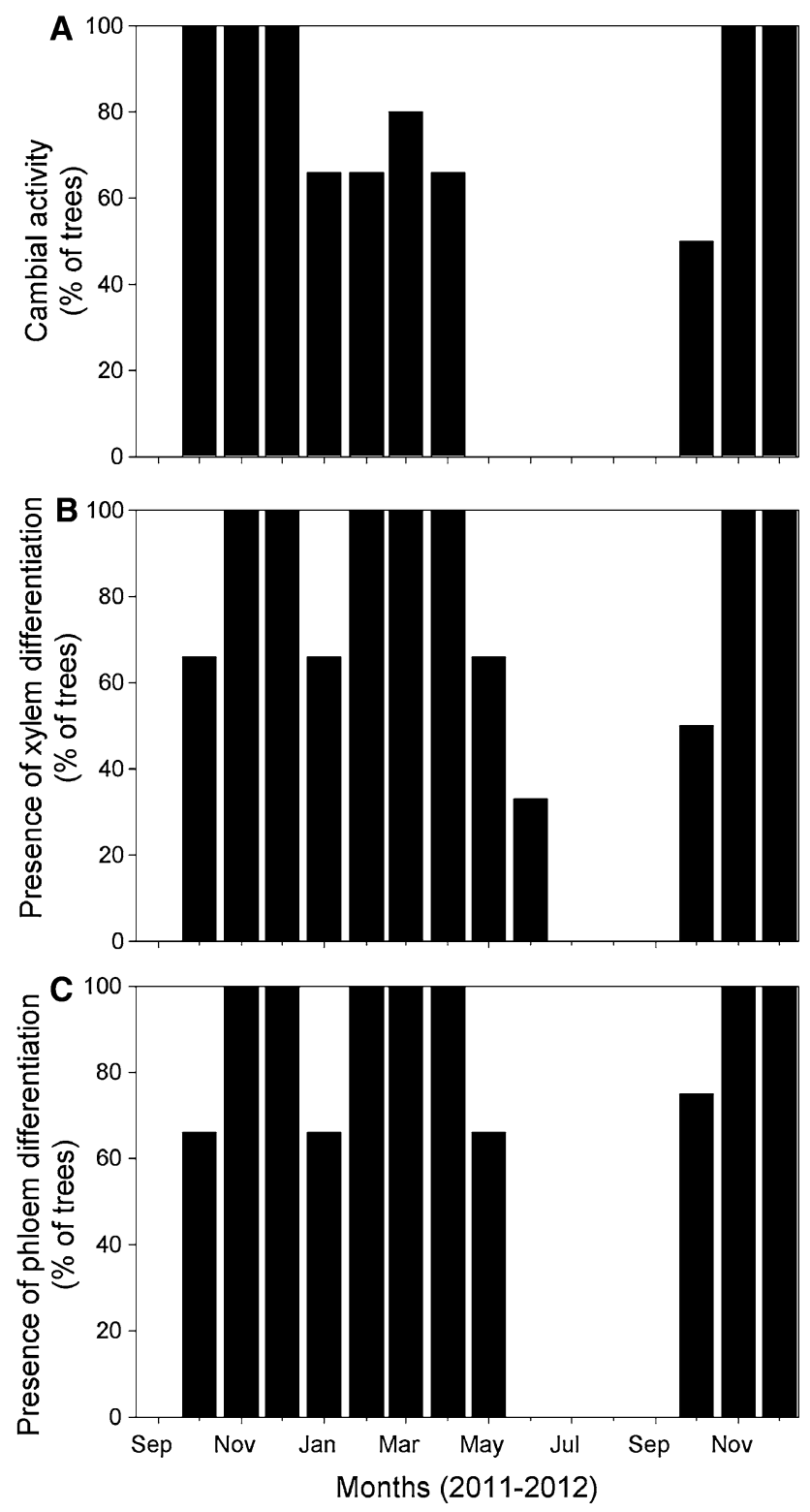

Fig. 2 Periods of cambial activity, differentiation of secondary vascular tissue and percentage of trees that showed these events (black columns)

of $36.2^{\circ} \mathrm{C}$ recorded in February 2012 (Fig. 4a). A variation of $2.9 \mathrm{~h}$ of daylight occurred during the year between the shortest and longest day, from a minimum of $10.6 \mathrm{~h}$ in June, at the winter solstice, to a maximum of $13.5 \mathrm{~h}$ in December, at the summer solstice (Fig. 4b). The site received a total of $2526 \mathrm{~mm}$ of rain during the study period, of which $1895.8 \mathrm{~mm}$ fell during 2012. The distribution of rainfall was irregular: two rainy seasons occurred, between October 2011 and June 2012 (1745 mm) and between October and December 2012 (682.1 mm). Two dry periods were also observed: in August-September 2011 (24.8 mm) and July-September 2012 (74.1 mm) (Fig. 4c).
Relationship between phenology and climatic and environmental features

The peaks of leaf primordium emergence and new leaves occurred during the dry period, when the photoperiod was increasing to $11 \mathrm{~h}$. Most mature leaves were present during the rainy season. Leaf senescence and leaf fall started in the rainy period, but the higher intensity of leaf fall occurred during the dry period. The onset of vascular cambium activity and the beginning of xylem and phloem differentiation occurred at the beginning of the rainy season, when the mean temperature was $21.7^{\circ} \mathrm{C}$, and day length was close to $12 \mathrm{~h}$. The dormancy of the vascular cambium started when rainy events were still abundant, with a mean temperature of $18.9{ }^{\circ} \mathrm{C}$ and day length of less than $12 \mathrm{~h}$.

\section{Coefficients of variation from climatic and environmental features}

In a time window of 30 days, both leaf primordium emergence and onset of vascular cambium activity showed the same pattern as the weather coefficient of variation (Fig. 5). The minimum, mean and maximum temperatures, as well as photoperiod, showed lower coefficients of variation within the time window (between 0.06 and 16.09), while precipitation showed higher values (141 for leaf primordium emergence, between 61 and 141 for onset of vascular cambium activity). Variations in the coefficients of variation of rainfall and photoperiod were constant, while the coefficients of minimum, mean and maximum temperature showed the greatest variability.

\section{Discussion}

\section{Periodicity of meristem activity}

In this study, the growth dynamics of apical and lateral meristems of $K$. grandiflora were monitored monthly from September 2011 to December 2012. The results show that this species has a clear seasonal pattern in leaf production, cambium activity and differentiation of secondary vascular tissues. Tropical ecosystems are composed of a mosaic of functional types, where apical and lateral seasonal growth is one of the patterns (see Borchert 1999, 2000). The seasonal apical and lateral growth in $K$. grandiflora represents a variation in leaf development and radial growth over time, and confirms the existence of seasonal growth in Cerrado species. Regarding the functional type, the results show that $K$. grandiflora is a deciduous species. Similar results were found in $K$. coriacea, a sympatric deciduous species, where the leafless period ranged between 20 and 30 days (see Coradin 2000; Lenza and Klink 2006). 


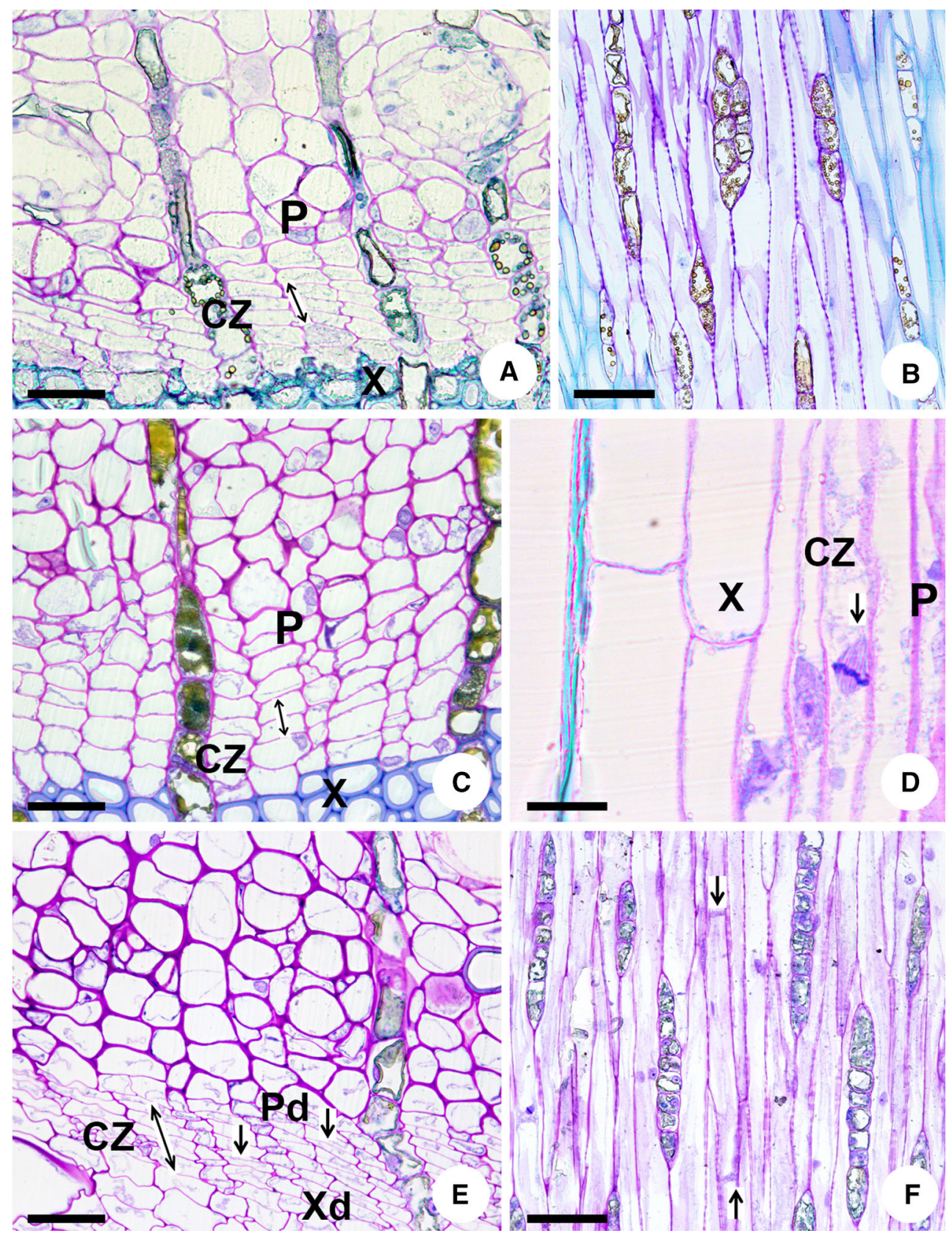

Fig. 3 Cambial activity and differentiation of vascular tissues of $K$. grandiflora. a, b dormant cambium. a Narrow cambial zone in transverse section in September 2011 (double arrow). b Fusiform cambial cells with beaded aspect of radial walls in tangential sections. c-f Active cambium. c Cambium with dormant aspect in transverse section of October 2011, without signs of cell division in cambial zone (double arrow), but with presence of mitosis in a cell from

\section{Leaf development and cambial activity}

In $K$. grandiflora, the onset of cambial activity in the main stem occurred when the new leaves were completing their development, 2 months after leaf primordium emergence. The scientific literature is rich in examples of tropical cambial zone at radial view in October 2011 (d). e Active cambium in November 2011, with phloem (Pd) and xylem (Xd) differentiation; arrows show new cell walls formed in cambial zone (double arrow). f Thin cell walls and phragmoplast (arrows) in tangential section. Scale bar d $20 \mu \mathrm{m} ; \mathbf{a}, \mathbf{c}, \mathbf{e}=50 \mu \mathrm{m} ; \mathbf{b}, \mathbf{f} 100 \mu \mathrm{m}$. $C Z$ cambial zone; $X$ secondary xylem; $P$ secondary phloem

species with the cambium reactivating either before, during or after bud opening (see Venugopal and Krishnamurthy 1987; Rao and Rajput 1999; Rajput and Rao 2001a, b), indicating the co-existence of distinct patterns relating bud opening and cambium reactivation in plants. As in $K$. grandiflora, in some diffuse-porous deciduous species the 

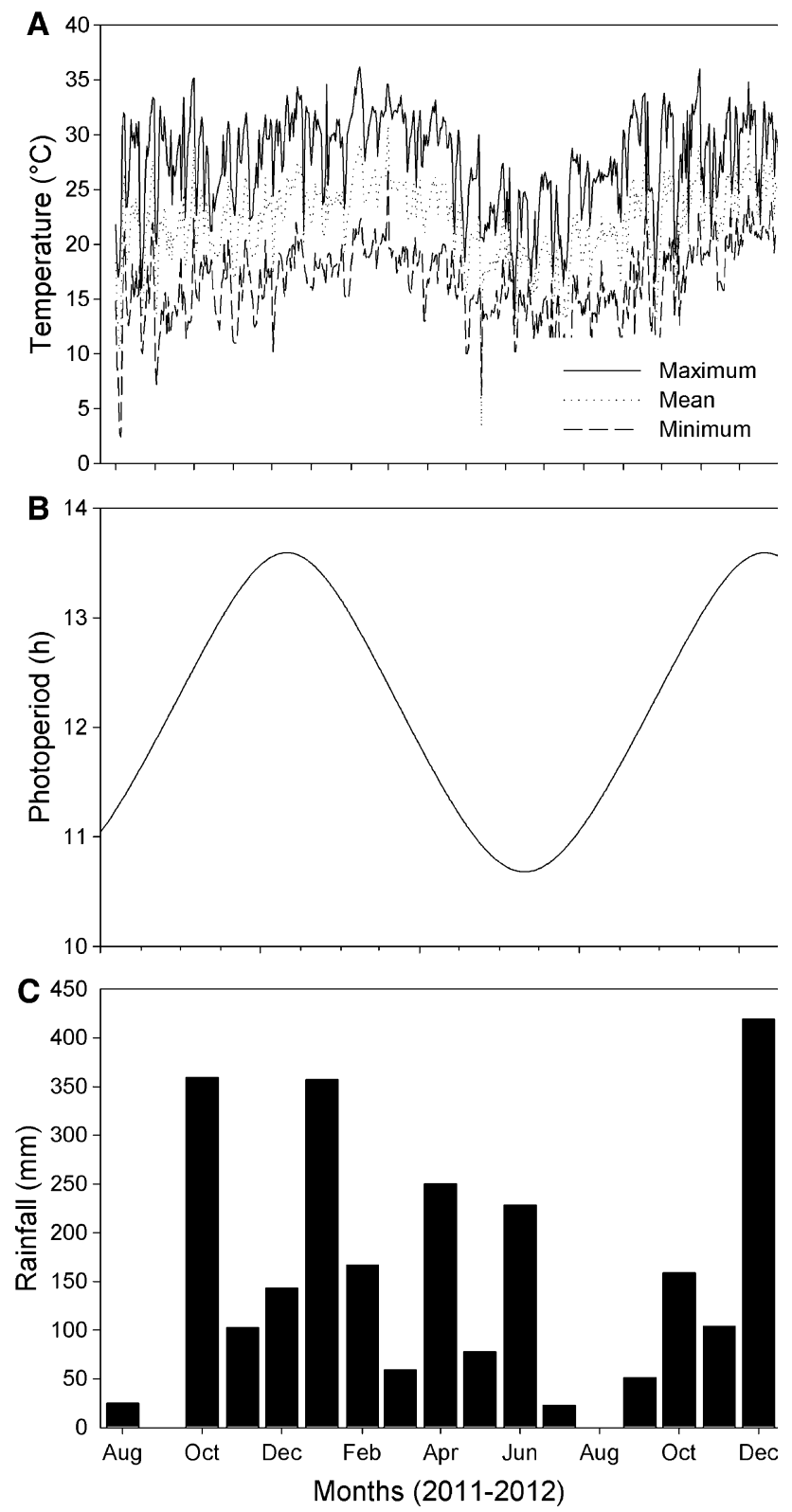

Fig. 4 Climatic and environmental features (temperature, photoperiod and rainfall) during the study period (from August 2011 to December 2012)

resumption of cambial activity and formation of the first vessel elements occur after bud opening (see $\mathrm{Lu}$ and Chiang 1975; Dave and Rao 1982; Suzuki et al. 1996), and it seems that this is the common pattern among these species.

Some authors propose that the reactivation of vascular cambium is related to plant hormones, in particular auxin (Larson 1969; Lachaud et al. 1999; Li et al. 2013). In trees, most auxin is produced in the apical regions during leaf emergence and expansion (Berleth et al. 2000; Ljung et al. 2001; Aloni et al. 2003), and moves basipetally along the stem (Sachs 2000). Larson (1969) proposed that the auxin produced in apical buds is responsible for the basipetal

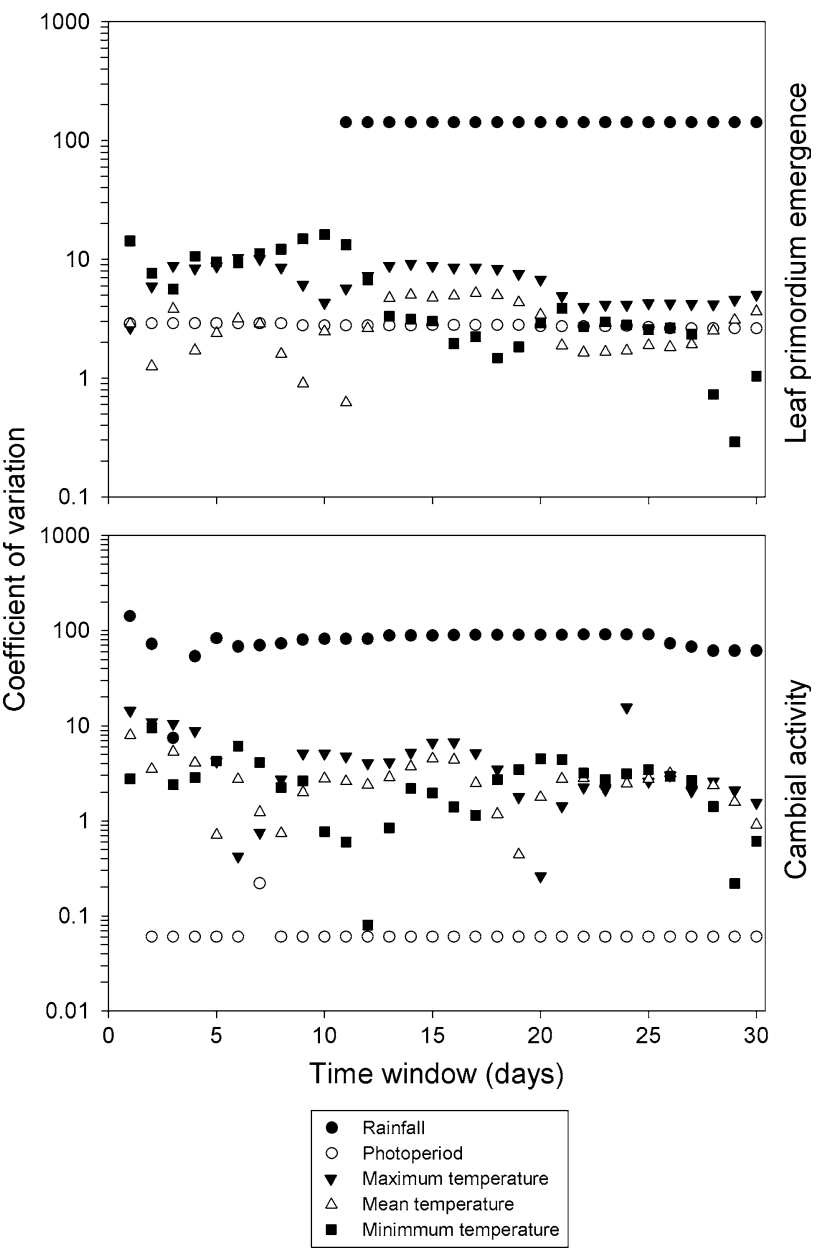

Fig. 5 Coefficients of variation from weather features in a time window of 30 days before leaf primordium emergence and onset of vascular cambium

reactivation of the vascular cambium, leading to a temporal lag between auxin production and the onset of the vascular cambium. However, in some species the resumption of cambial activity occurs before bud burst (Rossi et al. 2009; Li et al. 2013), suggesting that cambium reactivation may be more related to the sensitivity of cambium cells to the presence of auxin in the cambial zone, irrespective of its amount (Baba et al. 2011). In addition, manipulation experiments with local heating of the stem induced a resumption of cambial growth in conifer species, indicating that this meristem does not necessarily require auxin from young needles for its reactivation (Gričar et al. 2006; Begum et al. 2010). However, the observed lag between leaf primordium emergence and onset of cambium activity in $K$. grandiflora supports the idea proposed by Larson. In this species, it is possible that the auxin produced in apical buds may be involved with the resumption of cambial activity.

In both years, the onset of cambial activity occurred when leaves of the new crown were almost fully expanded 
and mature. Furthermore, as observed in other tropical species, the central period of cambial activity and differentiation of secondary vascular tissues occurred when trees were with completely developed foliage (Rajput and Rao 2001a; Marcati et al. 2006a, 2008; Trouet et al. 2012). The leaves are the main organ related to the production of the carbohydrates and hormones, such as auxin, necessary for the growth and development of the plant (Kozlowski et al. 1991; Ljung et al. 2001). The young leaves are photosynthetically active, but the use of reserves for their respiration usually exceeds the production of photosynthates by photosynthesis, therefore their early growth is strongly dependent on the carbohydrates stored in the stem in the form of starch, or in the nearby old leaves (Kozlowski et al. 1991; Deslauriers et al. 2014). As K. grandiflora is a deciduous species, canopy renewal occurs during a determinate moment of the year, and the new foliage takes 1-2 months to complete its development. Thus, cambium activity and differentiation of the vascular tissues occur when the leaves have completed their development and can act as active sources of carbon, supplying the growth of lateral tissues with recently-produced photosynthates.

\section{Meristem reactivation versus climatic and environmental features}

In $K$. grandiflora, leaf primordium emergence and the onset of vascular cambium activity occurred when photoperiod was increasing, while the cambium became dormant when photoperiod was decreasing. Moreover, both leaf primordium emergence and cambium reactivation showed low coefficients of variation of photoperiod in the 30-day time window before these events, indicating a strong homogeneity of this environmental factor between the two study years. The annual cycle of change in photoperiod represents a constant signal for plants (see Rossi et al. 2006), and the perception of light by phytochrome provides a temporal mechanism that ensures that bud opening and the onset of cambium occur at an appropriate time of the year (Smith 2000). Our data suggest that changes in photoperiod may explain the observed synchronization of both leaf primordium emergence and onset of cambium, and corroborates the relationships between phenology and photoperiod in tropical species (Rivera et al. 2002; Yáñez-Espinosa et al. 2006).

Temperature also showed low coefficients of variation for both leaf primordium emergence and onset of cambium activity, providing evidence on the importance of this climatic factor for growth resumption in this species. In temperate regions, the breaking of dormancy and cambium reactivation are directly linked to temperature (Wesołowski and Rowiński 2006; Deslauriers et al. 2008; Caffarra and Donnelly 2011). For dormancy breaking, it is necessary that the plants are exposed to low temperatures (chilling process), and accumulate a certain heat sum (forcing process). For the onset of cambium, Deslauriers et al. (2008) observed that high spring temperatures above the historical average promoted both cambium reactivation and xylogenesis in a conifer species at the Italian timberline. However, for tropical species, information on the relationship between temperature and growth reactivation is still scarce, and few papers report a positive relationship between maximum or minimum temperature and apical and lateral growth (see Ajmal and Iqbal 1987; Rajput and Rao 2001a; Yáñez-Espinosa et al. 2006; Venugopal and Liangkuwang 2007).

Leaf primordium emergence occurred during the dry season, when rainfall was low, and precipitation showed high coefficients of variation within the 30-day time window before bud opening. These results suggest that rainfall is not a determinant feature for bud opening in $K$. grandiflora. Similar results were observed in other tropical ecosystems, where bud opening occurred at the end of the dry season (Deshpande and Rajendrababu 1985; Rao and Rajput 2001; Rivera et al. 2002). Some tropical species access the water stored in deep soil or in stem tissues in the dry season, which enables them to produce new leaves before the onset of rains (Borchert 1999). Jackson et al. (1999) observed that another Cerrado Kielmeyera species accesses water in the deep soil, allowing it to produce new leaves during the dry period. Similarly, K. grandiflora probably accesses the water in deep soil to begin producing new leaves during the dry period.

The onset of vascular cambium in many tropical species occurs together with the onset of rains, and the cambial activity and secondary tissue differentiation are correlated to the rainy season (see Rajput and Rao 2001a; Yáñez-Espinosa et al. 2006; Krepkowski et al. 2011). However, in studies that explored cambial activity at the histological level, it is observed that the onset of cambial activity may occur at the end of the dry season, when the first rains have still not fallen (Dave and Rao 1982; Rajput and Rao 2001b). In the present study the onset of cambial activity coincides with the beginning of the rainy season, but the high coefficients of variation of rainfall data over the 30-day time window before the onset of cambium show that rainfall is highly variable, indicating that this factor is not a good indicator for the resumption of cambial activity. However, like other tropical species, it seems that rainfall is important for cambial activity as a whole, since the period of cambial activity in $K$. grandiflora overlaps with the core of the rainy season (see Rajput and Rao 2000; Marcati et al. 2006a, 2008; Trouet et al. 2012; Wang et al. 2013).

The cambium completed its activity in May 2012, a period with heavy rains and high temperatures, 2 months before the end of xylem and phloem differentiation. The process of formation of xylem and phloem is composed of 
a number of steps initiated with the formation of new cells by the cambium (Fukuda 1996). Moreover, the completion of secondary xylem differentiation is not always simultaneous with the onset of cambium dormancy (Gričar et al. 2005). Rossi et al. (2006) observed that the highest growth rates in conifers occurred before the period of the year with higher temperatures, allowing plants to complete the deposition of secondary wall and lignification before winter, in a period when conditions are still favourable to growth. The Cerrado domain is characterized by a dry and cold winter, when the monthly rainfall is less than $60 \mathrm{~mm}$ and temperatures can dip to freezing (Coutinho 2002). Our results suggest that cambium dormancy in $K$. grandiflora in a period still favourable for growth occurs before winter so that secondary vascular tissues finish differentiation under favourable conditions. These results are in agreement with the observations on other tropical species experiencing seasonal environments (Lu and Chiang 1975; Deshpande and Rajendrababu 1985).

The results show that both apical and lateral growth are seasonal events in $K$. grandiflora. The onset of cambial activity occurs after bud opening, corroborating the pattern for deciduous tropical species with diffuse-porous wood. Photoperiod and temperature are more constant signals for bud opening and the onset of cambial activity than rainfall, and development of vascular tissues occurs when new crown leaves are mature and rainfall is abundant. In addition, the cambium dormancy begins during the rainy season, allowing vascular tissue development to be completed under favourable conditions. In conclusion, apical and lateral growth are seasonal events in Cerrado species, and are related to each other. A set of climatic and environmental features is related with seasonal growth, among which photoperiod and temperature seem most likely to be important in the regulation of these events.

Author contribution statement F. Bosio and C. R. Marcati designed the experiment. F. Bosio collected and prepared the samples, and realized the measurements. F. Bosio, S. Rossi and C. R. Marcati performed data analysis and wrote the manuscript.

Acknowledgements This work was supported by Fundação de Amparo à Pesquisa do Estado de São Paulo (FAPESP) (2009/177789, 2015/14954-1). F. Bosio thanks the Coordenação de Aperfeiçoamento de Pessoal de Nível Superior (CAPES) and Fonds de la Recherche du Québec-Nature et Technologies (187055) for scholarships. We thank Liliane Catarina Pereira for assistance in laboratory procedures and Wolker Bittrich by species identification. Special thanks to the weather station staff of Faculdade de Ciências Agronômicas, Univ Estadual Paulista, campus Botucatu, for providing the meteorological data.

\section{Compliance with ethical standards}

Conflict of interest The authors declare that they have no conflict of interest.

\section{References}

Ajmal S, Iqbal M (1987) Annual rhythm of cambial activity in Streblus asper. IAWA J 8:275-283

Aljaro ME, Avila G, Hoffmann A, Kummerow J (1972) The annual rhythm of cambial activity in two woody species of the Chilean "Matorral". Amer J Bot 59:879-885

Aloni R, Schwalm K, Langhans M, Ullrich CI (2003) Gradual shifts in sites of free-auxin production during leaf-primordium development and their role in vascular differentiation and leaf morphogenesis in Arabidopsis. Planta 216:841-853. doi:10. 1007/s00425-002-0937-8

Baba K, Karlberg A, Schmidt J, Schrader J, Hvidsten TR, Bako L, Bhalerao RP (2011) Activity-dormancy transition in the cambial meristem involves stage-specific modulation of auxin response in hybrid aspen. Proc Natl Acad Sci USA 108:3418-3423. doi:10.1073/pnas.1011506108

Begum S, Nakaba S, Oribe Y, Kubo T, Funada R (2010) Cambial sensitivity to rising temperatures by natural condition and artificial heating from late winter to early spring in the evergreen conifer Cryptomeria japonica. Trees 24:43-52. doi:10.1007/ s00468-009-0377-1

Bennett HS, Wyrick AD, Lee SW, McNeil JH (1976) Science and art in preparing tissues embedded in plastic for light microscopy, with special reference to glycol methacrylate, glass knives and simple stains. Stain Technl 51:71-97

Berleth T, Mattsson J, Hardtke CS (2000) Vascular continuity and auxin signals. Trends Plant Sci 5:387-393

Berlyn GP, Miksche JP (1976) Botanical microtechnique and cytochemstry. The Iowa State University Press, Ames

Borchert R (1999) Climatic periodicity, phenology and cambium activity in tropical dry forest trees. IAWA J 20:239-248

Borchert R (2000) Organismic and environmental controls of bud growth in tropical trees. In: Víemont JD, Crabbé J (eds) Dormancy in plants: from whole plant behavior to cellular control. CAB International, Wallingford, pp 87-107

Caddah MK, Mayer JLS, Bittrich V, Amaral MCE (2012) Species limits in the Kielmeyera coriacea complex (Calophyllaceae)-a multidisciplinary approach. Bot J Linn Soc 168:101-115

Caffarra A, Donnelly A (2011) The ecological significance of phenology in four different tree species: effects of light and temperature on bud burst. Int J Biometeorol 55:711-721. doi:10. 1007/s00484-010-0386-1

Clarke A, Gaston KJ (2006) Climate, energy and diversity. Proc R Soc B 273:2257-2266. doi:10.1098/rspb.2006.3545

Coradin VTR (2000) Formação de anéis de crescimento e sazonalidade da atividade cambial de dez espécies lenhosas do cerrado. PhD Thesis, Universidade de Brasília

Costa MS, Vasconcelos TJ, Barros CF, Callado CH (2013) Does growth rhythm of a widespread species change in distinct growth sites? IAWA J 34:498-509. doi:10.1163/22941932-00000040

Coutinho LM (2002) O bioma do cerrado. In: Klein AL (ed) Eugen Warming e o cerrado brasileiro. UNESP, Imprensa Oficial do Estado, São Paulo, pp 77-92

Coutinho LM (2006) O conceito de bioma. Acta Bot Bras 20:13-23

Cunha AR, Martins D (2009) Classificação climática para os municípios de Botucatu e São Manoel, SP. Irriga 14:1-11

Dave YS, Rao KS (1982) Seasonal activity of the vascular cambium in Gmelina arborea Roxb. IAWA J 3:59-65

Deshpande BP, Rajendrababu T (1985) Seasonal changes in the structure of the secondary phloem of Grewia tiliaefolia, a deciduous tree from India. Ann Bot 56:61-72

Deslauriers A, Rossi S, Anfodillo T, Saracino A (2008) Cambial phenology, wood formation and temperature thresholds in two 
contrasting years at high altitude in southern Italy. Tree Physiol 28:863-871

Deslauriers A, Beaulieu M, Balducci L, Giovannelli A, Gagnon MJ, Rossi S (2014) Impact of warming and drought on carbon balance related to wood formation in black spruce. Ann Bot 114:335-345. doi:10.1093/aob/mcu111

Dié A, Kitin P, Kouamé FNG, Van den Bulcke J, Van Acker J, Beeckman H (2012) Fluctuations of cambial activity in relation to precipitation result in annual rings and intra-annual growth zones of xylem and phloem in teak (Tectona grandis) in Ivory Coast. Ann Bot 110:861-873. doi:10.1093/aob/mcs145

Durigan G, Siqueira MF, Franco GADC, Contieri WA (2004) A flora arbustivo-arbórea do Médio Paranapanema: base para a restauração dos ecossistemas naturais. In: Vilas-Boas O, Durigan $G$ (eds) Pesquisas em conservação e recuperação ambiental no Oeste Paulista: resultados da cooperação Brasil/Japão. Páginas e Letras, São Paulo, pp 199-239

Evert RF (1963) The cambium and seasonal development of the phloem in Pyrus malus. Amer J Bot 50:149-159

Evert RF (2006) Esau's plant anatomy: meristems, cells, and tissues of the plant body: their structure, function, and development, $3 \mathrm{rd}$ edn. Wiley INC, New Jersey

Farrar JJ, Evert RF (1997) Ultrastructure of cell division in the fusiform cells of the vascular cambium of Robinia pseudoacacia. Trees 11:203-215

Fournier LA (1974) Un método cuantitativo para la medición de características fenológicas em árboles. Turrialba 24:422-423

Frankenstein C, Eckstein D, Schmitt U (2005) The onset of cambium activity-a matter of agreement? Dendrochronologia 23:57-62. doi:10.1016/j.dendro.2005.07.007

Fukuda H (1996) Xylogenesis: initiation, progression, and cell death. Annu Rev Plant Physiol Plant Mol Biol 47:299-325. doi:10. 1146/annurev.arplant.47.1.299

Gričar J, Čufar K, Oven P, Schmitt U (2005) Differentiation of terminal latewood tracheids in silver fir trees during autumn. Ann Bot 95:959-965. doi:10.1093/aob/mci112

Gričar J, Zupančič M, Čufar K, Koch G, Schmitt UWE, Oven P (2006) Effect of local heating and cooling on cambial activity and cell differentiation in the stem of Norway spruce (Picea abies). Ann Bot 97:943-951. doi:10.1093/aob/mc1050

Jackson PC, Meinzer FC, Bustamante M, Goldstein G, Franco A, Rundel PW, Caldas L, Igler E, Causin F (1999) Partitioning of soil water among tree species in a Brazilian Cerrado ecosystem. Tree Physiol 19:717-724

Kozlowski TT, Kramer Paul J, Pallardy SG (1991) The physiological ecology of woody plants. Academmic Press, San Diego

Krepkowski J, Bräuning A, Gebrekirstos A, Strobl S (2011) Cambial growth dynamics and climatic control of different tree life forms in tropical mountain forest in Ethiopia. Trees 25:59-70. doi:10. 1007/s00468-010-0460-7

Lachaud S, Catesson AM, Bonnemain JL (1999) Structure and functions of the vascular cambium. $\mathrm{C} R$ Acad Sci III 322:633-650

Larson PR (1969) Wood formation and the concept of wood quality. Bulletin no. 74. New Haven, CT: Yale Univ Sch For 54p

Lenza E, Klink CA (2006) Comportamento fenológico de espécies lenhosas em um cerrado sentido restrito de Brasília, DF. Revista Brasil Bot 29:627-638

Li WF, Ding Q, Cui KM, He XQ (2013) Cambium reactivation independent of bud unfolding involves de novo IAA biosynthesis in cambium regions in Populus tomentosa Carr. Acta Physiol Plant 35:1827-1836. doi:10.1007/s11738-013-1220-2

Ljung K, Bhalerao RP, Sandberg G (2001) Sites and homeostatic control of auxin biosynthesis in Arabidopsis during vegetative growth. Plant J. 28:465-474
Lu CY, Chiang SHT (1975) Seasonal activity of the cambium in the young branch of Liquidambar formosana Hance. Taiwania 20:32-47

Marcati CR, Angyalossy V, Evert RF (2006a) Seasonal variation in wood formation of Cedrela fissilis (Meliaceae). IAWA J 27:199-211

Marcati CR, Oliveira JS, Machado SR (2006b) Growth rings in cerrado woody species: occurrence and anatomical markers. Biota Neotrop 6. http://www.biotaneotropica.org.br/v6n3/pt/ abstract?article+bn00206032006. Accessed 01 June 2011

Marcati CR, Milanez CRD, Machado SR (2008) Seasonal development of secondary xylem and phloem in Schizolobium parahyba (Vell.) Blake (Leguminosae: Caesalpinioideae). Trees 22:3-12. doi:10.1007/s00468-007-0173-8

Morel H, Mangenet T, Beauchêne J, Ruelle J, Nicolini E, Heuret P, Thibaut B (2015) Seasonal variations in phenological traits: leaf shedding and cambial activity in Parkia nitida Miq. and Parkia velutina Benoist (Fabaceae) in tropical rainforest. Trees 29:973-984. doi:10.1007/s00468-015-1177-4

Morellato LPC, Rodrigues RR, Leitão-Filho HD, Joly CA (1989) Estudo comparativo da fenologia de espécies arbóreas de floresta de altitude e floresta mesófila semidecídua na Serra do Japi, Jundiaí, São Paulo. Revta Brasil Bot 12:85-98

Motta PEF, Curi IN, Franzmeier DP (2002) Relation of soils and geomorphic surfaces in the Brazilian Cerrado. In: Oliveira PS, Marquis RJ (eds) The cerrados of Brazil. Columbia University Press, New York, pp 13-32

O'Brien TP, McCully ME (1981) The study of plant structure: principles and selected methods. Termarcarphi Pty LTD, Melbourne

O'Brien TP, Feder N, McCully ME (1964) Polychromatic staining of plant cell walls by toluidine blue O. Protoplasma 59:368-373

Oliveira-Filho AT, Ratter JA (2002) Relation of soils and geomorphic surfaces in the Brazilian Cerrado. In: Oliveira PS, Marquis RJ (eds) The cerrados of Brazil. Columbia University Press, New York, pp 91-120

Rajput KS, Rao KS (2000) Cambial activity and development of wood in Acacia nilotica (L.) Del. growing in different forests of Gujarat state. Flora 195:165-171

Rajput KS, Rao KS (2001a) Cambial activity and development of xylem in Tamarindus indica L. growing in different forests of Gujarat state. Acta Bot Hung 43:379-390

Rajput KS, Rao KS (2001b) Cambial anatomy and annual rhythm of secondary xylem development in the twigs of Azadirachta indica A. Juss. (Meliaceae) growing in different forests of Gujarat State. J Sustain For 14:115-127

Rao KS, Rajput KS (1999) Seasonal behaviour of vascular cambium in teak (Tectona grandis) growing in moist deciduous and dry deciduous forests. IAWA J 20:85-93

Rao KS, Rajput KS (2001) Relationship between seasonal cambial activity, development of xylem and phenology in Azadirachta indica growing in different forests of Gujarat State. Ann For Sci 58:691-698

Rivera G, Elliott S, Caldas LS, Nicolossi G, Coradin VT, Borchert R (2002) Increasing day-length induces spring flushing of tropical dry forest trees in the absence of rain. Trees 16:445-456. doi:10. 1007/s00468-002-0185-3

Rossi S, Deslauriers A, Anfodillo T, Morin H, Saracino A, Motta R, Borghetti M (2006) Conifers in cold environments synchronize maximum growth rate of tree-ring formation with day length. New Phytol 170:301-310. doi:10.1111/j.1469-8137.2006.01660.

Rossi S, Rathgeber CB, Deslauriers A (2009) Comparing needle and shoot phenology with xylem development on three conifer species in Italy. Ann For Sci 66:1-8. doi:10.1051/forest/2008088 
Sachs T (2000) Integrating cellular and organismic aspects of vascular differentiation. Plant Cell Physiol 41:649-656

Santos MF, Serafim H, Sano PT (2011) Fisionomia e composição da vegetação florestal na Serra do Cipó, MG, Brasil. Acta Bot Bras 25:793-814

Smith H (2000) Phytochromes and light signal perception by plantsan emerging synthesis. Nature 407:585-591

Suzuki M, Yoda K, Suzuki H (1996) Phenological comparison of the onset of vessel formation between ring-porous and diffuseporous deciduous trees in a Japanese temperate forest. IAWA J $17: 431-444$

Time and Date (2014) Time and Date. http://www.timeanddate.com/ sun/brazil/sao-paulo. Accessed 24 March 2014

Trouet V, Mukelabai M, Verheyden A, Beeckman H (2012) Cambial growth season of brevi-deciduous Brachystegia spiciformis trees from south central Africa restricted to less than 4 months. PLoS One 7:e47364. doi:10.1371/journal.pone.0047364

Venugopal N, Krishnamurthy KV (1987) Seasonal production of secondary xylem in the twigs of certain tropical trees. IAWA J $8: 31-40$
Venugopal N, Liangkuwang MG (2007) Cambial activity and annual rhythm of xylem production of elephant apple tree (Dillenia indica Linn.) in relation to phenology and climatic factor growing in sub-tropical wet forest of northeast India. Trees 21:101-110. doi:10.1007/s00468-006-0101-3

Wang KH, Nobuchi T, Abdul Azim AA, Sahri MH (2013) Seasonal variations in cambial anatomy of plantation-grown Azadirachta excelsa. J Trop For Sci 25:111-117

Wesołowski T, Rowiński P (2006) Timing of bud burst and tree-leaf development in a multispecies temperate forest. For Ecol Manage 237:387-393. doi:10.1016/j.foreco.2006.09.061

Worbes M (1995) How to measure growth dynamics in tropical trees: a review. IAWA $\mathrm{J}$ 16:337-351

Yáñez-Espinosa L, Terrazas T, Lopez-Mata L (2006) Integrated analysis of tropical trees growth: a multivariate approach. Ann Bot 98:637-645. doi:10.1093/aob/mcl142 